\title{
A Study on Factors Impacting on Profitability: The Case of Vietnam
}

\author{
Huy Quang Bui, Duc Viet Nguyen, Do Duc Manh Tran \\ Advanced Finance 59, National Economics University, Vietnam \\ Phuong Thao Hoang, Minh Huong Pham \\ Advanced Accounting 59, National Economics University, Vietnam \\ Manh Dung Tran \\ National Economics University, Vietnam \\ Thi Thu Trang Nguyen \\ Joint Stock Commercial Bank for Foreign Trade of Vietnam
}

\begin{abstract}
This study is conducted to investigate factors influencing the profitability of the Vietnamese food processing firms. Data was collected from audited financial statements from listed food processing firms on the Vietnam Stock Exchange. Panel regression model was applied in this study (PLS). The testing methods used in this research were Pearson model; Modified Wald Test, Wooldridge test (for autocorreclation in panel data), Hausman model, especially the relationship between FEM and REM as well as Multicollinearity test based on VIF coeficient. The results shows that DR, SDR and LDR have negative impacts on profitability. In contrast, TDTELT have positive impacts on the profitability. FATA and SIZE impact return on asset (ROA) without statistical significance. SIZE has positive impact on return on equity (ROE) while it impacts negatively on profit margin (PM). Moreover, AGE, GDP growth, and inflation do not have impact on profitability.
\end{abstract}

Keywords: Factors, Return on assets, Food processing firms, Vietnam

DOI: $10.7176 /$ RJFA/11-10-07

Publication date:May $31^{\text {st }} 2020$

\section{Introduction}

The determinants impacting performance of firms have attracted numerous attention and research of scholars in the field of corporate finance for decades. The capital structure of a business reflects the level of debt and equity used to finance its assets. Specifically, the level of using debt will affect the manager's behavior as well as their financial decisions; hence, it tremendously affects the performance of the business (Harris \& Raviv, 1991; Graham \& Harvey, 2001). It is said that considering the impact of factors on profitability ratio is of necessity. By doing so, it not only increases the operational efficiency but also maximizes shareholder assets.

In fact, a successful administrator is the one who can determine the optimal capital structure by minimizing the financial cost of the company thereby maximizing the profits. It can be inferred that the capital structure tremendously affects the performance of the firms.

In the past 10 years, the food processing industry has shown remarkably its movement towards modernization and industrialization. This sector is predicted to give priority to Vietnam's growth with vision towards 2030. Thanks to preferential policies which revolve around technologies, this industry possesses huge potentials to capture the majority of the market.

Meanwhile, prior studies about the impact of determinants upon the profitability of listed food firms on the Vietnam Stock Exchange have not been looked into much. Understanding about determinants influencing firms' profitability is a key to give the shareholders or investors better insights on whether the amount of capital they spend in a firm will gain returns or losses; thus they can limit risks. Therefore, a comprehensive study on the determinants influencing the profitability of listed food processing firms in Vietnam issue is of necessity.

\section{Theoretical framework}

\subsection{Determinants Influencing Profitability of Firms} Debt Ratio (DR)

\section{DR $=$ Total Debt/Total Assets}

Debt ratio is a financial ratio that assesses leverage level of the company. In other words, the debt ratio shows how amount of assets that the company must sell in order to pay off all of its liabilities. Dividing the total liabilities of the company (including current and noncurrent) by the company's total assets, we can calculate debt ratio.

It can be said that debt ratio is one of the very industry-specific ratio. It should be examined against competitors and along with other ratios such as number of times interest earned, etc. 
Because creditors are always worried about repaid, it can be said that the debt ratio is the company's basic solvency ratio. Debt ratio will increase as companies borrow more money, which means that creditors will no longer be able to lend them money...Lower debt ratios often imply a more stable business with the potential of longevity because a lower rate company also has lower total debt. Very high debt ratios show a high risk for both creditors and equity investors. The company might not be able to raise any more money or it may not be able to get financing on good terms due to the high risk. To develop their operations, companies with higher debt ratios should find ways to finance the equity.

\section{Short Term Debt to Total Assets (SDR)}

\section{SDR $=$ Short-term Debt/Total Assets}

The ratio of short-term debt indicates the probability that a company will be able to provide payments to its unpaid short-term liabilities. Short-term debt to total assets is calculated by dividing short-term debt to total assets of the company.

Short-term debt to total assets calculates the amount of liabilities within one year for the total debt (Vo and Bui, 2012). Ratio point out whether a company will be meet its instant financial obligations. A high ratio indicates a lack of liquidity because most of the company's debt ought to be met in current years. Because debt facilities can be withdrawn immediately, companies that depend on short-term capital are more defenseless to liquidity shocks than companies with long-term obligation financing.

\section{Long Term Debt to Total Assets (LDR)}

\section{LDR = Long-term Debt/Total Assets}

While the total debt to total assets ratio includes all debts, the long-term debt to assets ratio only takes into account long-term debts.

Long-term debt is debt that matures outstanding debt a company in more than one year. On the company's balance sheet, it is considered as a non-current liability. The ratio of long-term debt to total assets is a measure that represents the percentage of company's assets financed by long-term debt, including loans or other debt obligations lasting more than one year. The overall measure of a firm's long-term financial position is provided clearly by this ratio, especially its ability to meet the financial obligations for outstanding debts also included. The ratio of longterm debt to total assets is solvency ratio used to calculate the level of leverage of a company. Since this ratio is calculated annually, the reduction will indicate that the company is performing well and is less dependent on debt for their business needs. The percentage of a company's assets that liquidated to pay its long-term debt will be shown clearly through the results of long-term debt to total assets. The trend of choosing to finance debt assets instead of equity and the company's ability to repay debt over time can be considered through recalculation over multiple periods.

\section{Fixed Assets to Total Assets (FATA)}

\section{FATA $=$ Net Fixed Assets/Total Assets}

To calculate fixed assets to total assets, we will divide net fixed assets by total assets. Net fixed assets is defined as a measure of net book value of all fixed assets on the balance sheet at a given point time calculated by deducting accumulated depreciation. Fixed assets to total assets can also help investors as well as companies assess the stability of investing in fixed assets. So it can be asserted that the smaller the fixed assets to total assets coefficient, the higher the level of safety will be. As asset levels change, the percentage of likely assets that are required will be determined through fixed assets to total assets. When developing budgets, to verify whether the budget capital spending is consistent with historical experience or not, fixed assets to total assets will often be used as a cross check.

\section{Firms size}

Companies' board of directors are taking into consideration the optimal size of a business unit, that is generally a firm whose the average total cost (ATC) of production per unit is the lowest. But while taking decision about the size of a business unit or scale of operations often the various terms such as total assets or revenue, the firm and the industry are used in a confused way. In other words, firm size has been considered as an important variable indicating organizational profitability and many of the previous studies have tried to explore the effect of firm size on profit-generating ability of companies in varying major. However, the results of those prior studies have been reported with inconsistent and controversial conclusions, thus necessarily demand for further and specific investigation. Therefore, in this study authors are filling this hole by providing empirical statistics to prove that size has a clear effect on profitability. Normally, there is a positive relationship between firm size and profitability. However, in some cases, small corporations or companies gains huge profit and inversely as proved in many previous studies. In this research, authors discover the connection between the difference in size of food-processing companies and their financial performance. Therefore, authors select the independent variables below such as total assets, total sales and number of employees have been used as firm size indicators in this study. The preference for the 3 aforementioned index thanks to the fact that it facilitates the authors present the effects of different companies in their financial performance hence allowing for efficient comparison of corporation's profitability. 


\section{Years of operation}

Age symbolizes the length of time a subject has existed. The authors define firm age as the number of years of incorporation of the company; even though some believe that listing age, which expresses the years a company is listed on the stock exchange market should be the definitions for the age of the company.

As many other researches showed, there was a link between the capability of gaining profit and operating years. Generally, this relationship caused the conflicting interests. Specifically, many financial financialists and authors concluded that the firm age was positively related to the profit-generating ability while others reported the negative connection, which made this problem quite debatable. Despite the mix reaction, there is lack of articles that express the issue about years of operation and profitability in a clear and detailed way. Therefore, the authors are going to elaborate on the strong and certain relationship between operating years and profitability in this study.

\section{Economic growth rate}

Economic growth formula: (dY x 100\%)/Y In which: Y: scale of economy; $d Y$ : Growth

An economic growth rate is the percentage change in the value of all of the goods and services produced in a nation during a specific period of time, as compared to an earlier period. The economic growth rate is used to measure the temporary health of an economy over a certain period of time. The statistics and indexes are usually recorded and reported quarterly and annually. Many facts attest to the relationship between profitability and economic growth. In the first place, in the stage of economic growth, an overwhelming number of enterprises earn fairly huge profits. The markets are dominated by general confidence and optimism. A wholly different picture can be seen when economic growth is absent. In the duration of crisis, firm's profit tends towards zero, just a few enterprises generate modest profits and others suffer from losses.

\section{Inflation}

$$
\text { Inflation rate }=\frac{[\text { CPI of year }(n+1)-C P I \text { of year }(n)}{C P I \text { of year }(n)}
$$

In which: CPI: Consumer Price Index is a measure that examines the weighted average of prices of a basket of consumer goods and services, such as transportation, food, and medical care.

Inflation is a quantitative measure of the rate at which the average price level of a basket of selected goods and services in an economy increases over a period of time. Firms generally prefer inflation to be low and stable. If inflation rises above 3 or 4\%, firms' owner may worry about the rise in costs and full of uncertainties in the market. Inflation can also bring companies troubles with rising costs, falling profitability, and a decline in international competitiveness. However, inflation is not always badly affecting a companies' profitability, especially if they can increase the price to consumers more than their production costs rise. When the economy experiences the time of demand-pull inflation, during the period of upgrading economic growth, the firm will benefit from increasing demand, which enables companies to increase the price. In this case, it may be able to increase profit. Another advantages that companies are able to take is that inflations probably reduces the value of money. If a firm have a certain amount of debt, then paying back at the period of inflation may help decrease the real value of the debt. This can be explained that during the inflation time nominal revenue will be rising, which facilitates the firm pay off old loans. In this case, inflation is positively changed with the profitability of the firm.

\section{Total debt/ (total shareholder's equity + long-term debt)}

It is a complicated measurement in order to clearly understand the risk of refinancing. In addition, in short-term debt, it can be clearly seen that the possibility of refinancing is zero, while that of long-term debt is significantly higher. If the ratio is high, this illustrates the capability to handle the debt. Those who use a large amount of money to invest in operation process have a tendency to have a higher debt to equity ratio. Nevertheless, the lower ratio tells a condition when an entity has less or no reliance on borrowings to manage its finance operations.

\subsection{Profitabliity ratio}

According to Pham and Nguyen (2015), profitability ratios are classes of financial metrics that are used to assess a business's ability to generate earnings relative to its revenue, operating costs, balance sheet assets, and shareholders' equity over time through using data from a specific point in time. Profitability analysis is a component of enterprise resource planning (ERP) that allows administrators to forecast the profitability of a proposal or optimize the profitability of an existing project. There are various profitability ratios, which are used by firms to provide useful insights into the financial well-being and performance of the business. To analyze the percentage of the firm's revenue comprises profit, which opposed to business costs and expenses, people often analyze the following criteria:

\section{Profit margin $=$ Net income $/$ Net sales}

This percentage shows how many cents of profit for each dollar of sale the firm has produced. Defining profit margins can assist businesses determine surplus expenditure or underperforming business products and procedures. It is helpful data to have on hand when evaluating how the business moves forward as it grows and expands. Also, staying in touch with what profit margin helps the firm identify problems that the firm may have to run. 


\section{Return on equity $=$ Net income/Total shareholders' equity}

Return on equity signifies how good the firm is in generating returns on the investment it received from its shareholders. So if a firm has an ROE of say 1, it means Return 1 of common shareholding generates a net income of Return 1. This metric is particularly crucial from the view of an investor as he/ she utilizes it to assess how effectively the firm can use its investment to produce extra revenue.

According to Trinh (2013) investors prefer firms with greater ROEs. This can, however, be used as a benchmark for selecting stocks only within the same industry. The return on equity levels may vary even within the same sector if a firm chooses to give dividends and does not retain the profit generated as idle cash.

\section{Research methodology}

\subsection{Research Model}

The research aims to identify the impact of many factors such as debt ratio, short-term debt ratio, long-term debt ratio, fixed asset to total asset, size, years of operation, GDP growth, inflation and TD/(TE $+\mathrm{LT})$ on profitability of food processing firms. These items are expressed by the return, debt ratio, and others to the profit of listed food processing firms. Therefore, a regression model has been designed that carries the qualified determinants.

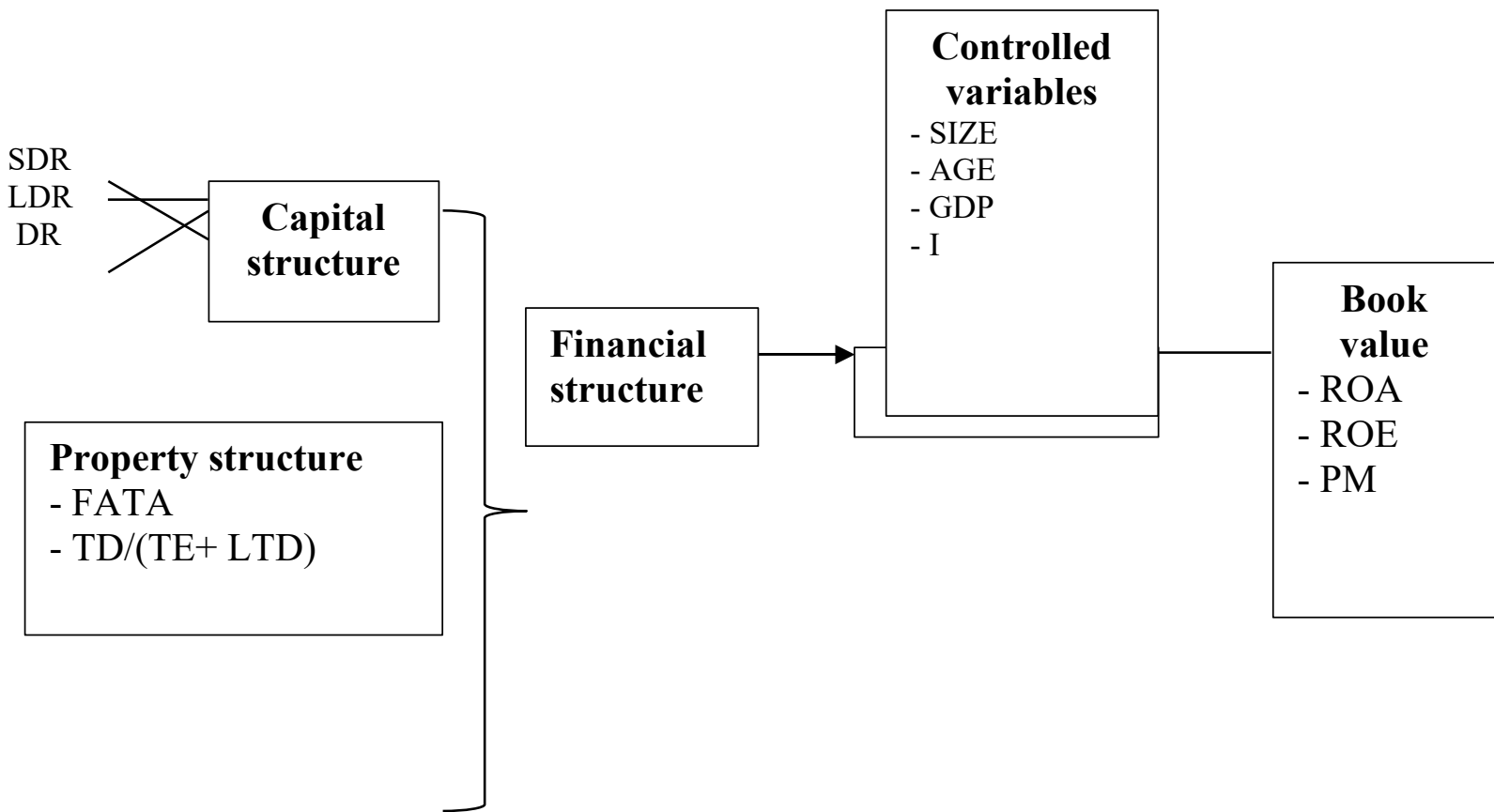

Figure 1: Research Model

Where: ROA: Return on Assets; ROE: Return on Equity; PM: Profit Margin

DR: Debt Ratio; SDR: Short term to Total Assets; LDR: Long term Debt to Total Assets; FATA: Fixed Assets to Total Assets; TD/(TE+LTD); SIZE: Size of firms; AGE: Years of operation; GDP: Economic Growth rate; I: Inflation

\subsection{Data Collection}

In thisistudy, the collected data is mainly a secondaryidata gathered fromiaudited financialistatements (including cashiflow statement; financialiposition statements or balanceisheet; comprehensiveiincome statement; and notes to the financialistatements) of the listed food processing firms on VietnamiStock Exchange (including Ho Chi Minh CityiStock Exchange (HSX) and HanoiiStock Exchange (HNX)) for a period of 7 years from 2012 to 2018. Besides, the study also refers the information from websites, some management statements of cophieu68.vn, finance.vietstock.com, hnx.com, icafef.vn, stockbiz.com, ect.

As a result, we chose 35 listed food processing firms on the stockimarket, corresponding to 140 observations. Then we putiin worksheets of Microsoft Excel andithen data was transferred to Stata14 foriprocessing and analyzing. Some basic information of revenueiof listed food processing firms areipresented in Tablei1: 
Table 1: Revenue in the Multiyear Dataset

\begin{tabular}{|c|c|c|c|c|c|c|c|c|c|c|c|c|}
\hline \multirow{2}{*}{$\begin{array}{l}\text { Revenue } \\
\text { (Mil dong) }\end{array}$} & \multicolumn{2}{|c|}{2012} & \multicolumn{2}{|c|}{2014} & \multicolumn{2}{|c|}{2015} & \multicolumn{2}{|c|}{2016} & \multicolumn{2}{|c|}{2017} & \multicolumn{2}{|c|}{2018} \\
\hline & No. & $\%$ & No. & $\%$ & No. & $\%$ & No. & $\%$ & No. & $\%$ & No. & $\%$ \\
\hline $\begin{array}{c}\text { Revenue }> \\
4,847,159\end{array}$ & 5 & 14.29 & 6 & 17.14 & 9 & 25.71 & 8 & 22.86 & 9 & 25.71 & 9 & 25.71 \\
\hline $\begin{array}{c}\text { Revenue }< \\
4,847,159\end{array}$ & 30 & 85.71 & 29 & 82.86 & 26 & 74.28 & 27 & 77.14 & 26 & 74.28 & 26 & 74.28 \\
\hline Total & 35 & 100 & 35 & 100 & 35 & 100 & 35 & 100 & 35 & 100 & 35 & 100 \\
\hline
\end{tabular}

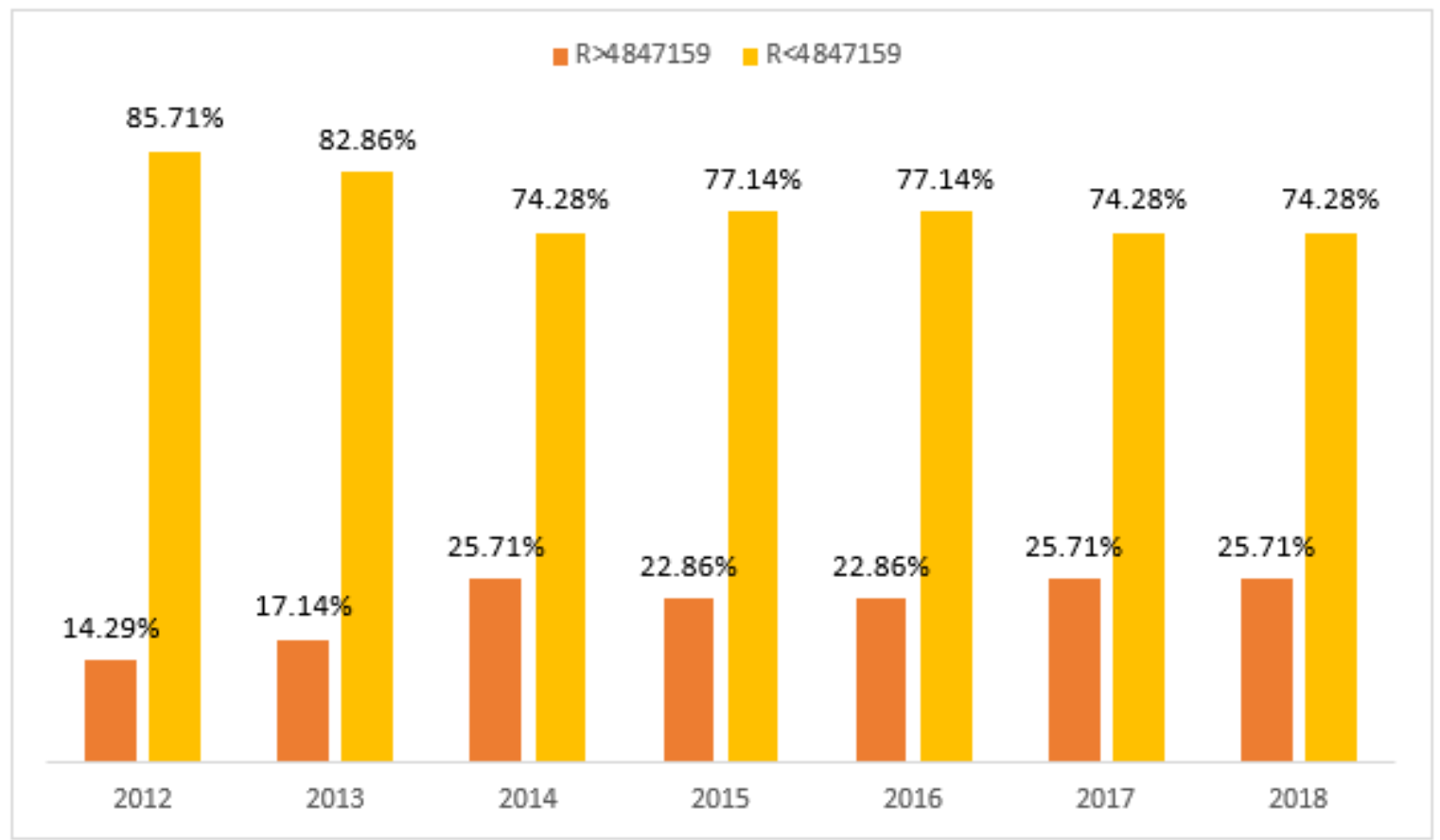

Figure 2: Revenue over the years

Data in Table 1idemonstratesithat from 2012 and 2013, the size of more than $82 \%$ of food processing firms isismaller than theiaverage industryisize. The main reason is the characteristicsiof domestic consumption. The market is dominated by large firms (beverages; animal and vegetable oil productionns; milk andidairy product processing) due to large initialiinvestment costs and theilevel of competition in thisifield is very high. Another reason is that theseifirms have long operating time (AGE), a great deal ofiexperience and grasp theineeds ofipartners and clients. At theipoint when there exists a large revenue with a stableifinancialiperformance, the firm can maintain aireasonable profit margin and debt ratio (DR). Because of their size, consumer's confidence in these firms is greater than the small firms. Besides, the market is alsoidominated by privateitraders (Meat and meat productsiprocessing and preserving; seafood and fishery productsiprocessing and preserving; vegetables and fruits processingiand preserving) as most consumers still have the habit ofibuying fresh meat andcvegetables at traditional markets instead ofibuying weeklyiat supermarkets.

In the period of 2014-2018, the difference in revenue over the years has been reduced. The number of food processing firms' size which is smaller than the average industry size has decreased approximated $75 \%$. The reason is that the market has gradually become more stable after the economy recession. Consumer's confidence in new and small businesses has also gradually increased over time. Although the disparity is still very large due to the industry characteristics, these are also good figures for the food processing industry in Vietnam. 
Table 2: Descriptive Statistics of Listed Food processing firm

\begin{tabular}{lrrrrrr}
\hline & \multicolumn{1}{l}{ Mean } & \multicolumn{1}{l}{ Median } & \multicolumn{1}{c}{ Max } & \multicolumn{1}{c}{ Min } & \multicolumn{1}{c}{ Std. Dev. } & Probability \\
\hline ROA & 0.102275 & 0.086472 & 0.7837 & -0.436211 & 0.091106 & 0 \\
ROE & 0.193462 & 0.160845 & 2.91825 & -0.53093 & 0.219918 & 0 \\
PM & 0.081801 & 0.067136 & 1.678176 & -2.026303 & 0.184154 & 0 \\
DR & 0.444152 & 0.406298 & 1.149477 & 0.09738 & 0.181348 & 0.037896 \\
SDR & 0.389073 & 0.348799 & 1.143964 & 0.087057 & 0.172274 & 0 \\
LDR & 0.055077 & 0.01727 & 0.506356 & 0 & 0.090942 & 0 \\
FATA & 0.373986 & 0.337104 & 0.90742 & 0.000146 & 0.204247 & 0.000036 \\
TD_TE_LT & 0.867163 & 0.630362 & 4.362314 & -7.984496 & 0.931402 & 0 \\
SIZE & 6.125882 & 5.968966 & 7.720671 & 4.093176 & 0.710375 & 0.460846 \\
GDP & 6.204286 & 6.21 & 7.08 & 5.25 & 0.648978 & 0.000025 \\
I & 4.51 & 3.54 & 9.09 & 0.88 & 2.45607 & 0.001313 \\
AGE & 16.45714 & 16 & 46 & 9 & 5.819977 & 0 \\
\hline
\end{tabular}

Table 2 presentsivalues based onisoftware of Stata 14. In particular, these include 6 components: minimumivalue (Minimum); highestivalue (Maximum); Averageivalues (Mean), standardideviations (Std.iDeviation) and the probability of 35 food processing firms are listed on the VietnamiStock Exchange in 7 years from 2012 to 2018. Asistated initheoretical framework, we calculate Return on assets (ROA); Return on equity (ROE) and Profit margin as proxies of profitability along with nineideterminants influencingithe performance of food processing firms.

\subsection{Techniques}

After the data collection step, data screening and putting in the worksheets are conducted. Then, we transfer data in Stata in order to process the model regression analysis together with testing methods of overcoming the defects of the models for concluding hypotheses designed with the case studies of listed food processing firms on Vietnam Stock Exchange.

The research sample includes 35 food processing firms listed on the stock market for the period from 2012 to 2018, so the panel least squares model (PLS) is utilised. The different testing methods used in this study are Hausman model, especially the relationship between FEM and Pooled OLS; Modified Wald Test, Wooldridge test (for autocorrelation in panel data), and lastly Multicollinearity test based on VIF coefficient and Pearson model.

\section{Hausman}

The Hausman test is a statistical hypothesis test in econometrics named after Durbin, Wu and Hausman. This algorithm is used to compare FEM and REM estimation methods. In other words, we use the Hausman model to test which one is more appropriate. In fact, the Hausman test is to see whether there exists an autocorrelation between $\varepsilon i$ and the other independent variables.

The Hausman test aims to determine whether a fixed or random impact model is suitable for a table data model. This test is to determine whether error "ui" correlates with the explanatory variables while The "Ho" hypothesis of the model states that there is no correlation between the error and the explanatory variable. To perform this test, you first run the fixed impact model (Command xtreg $\mathrm{y} x 1, \mathrm{fe}$ ) then save the estimated results (store fixed command), then run the random impact model (The command xtreg y $\mathrm{x} 1$, re) and also saves the result (store random command).

\section{The pooled OLS}

The Pooled model is essentially a normal OLS model, which is not categorized by year and then the Pooled model regression becomes a OLS model. This shows that if the POOL model is actually effective for data analysis, the use of analysis by FEM and REM models does not make much sense. That leads to the case where we just need to consider the OLS model for the data obtained and perform normal tests (8 OLS assumptions).

\section{Modified Wald Test}

The modified Wald test statistic, defined as:

$$
W=\sum_{i=1}^{N_{g}} \frac{\left(\widehat{\sigma}_{i}^{2}-\widehat{\sigma}^{2}\right)^{2}}{V_{i}}
$$

It will be distributed as $\chi 2[\mathrm{Ng}]$ under the null hypothesis. The discussion of Lagrange multiplier, likelihood ratio, and standard Wald test statistics points out whether these statistics are sensitive to the assumption of normality of the errors. The modified Wald statistic computed here is viable when the assumption of normality is 
violated, at least in asymptotic terms. In terms of small sample properties, simulations of the test statistic's properties have shown that its power is very low in the context of fixed effects with "large N, small T" panels. In that circumstance, the test should be used with caution.

\section{Wooldridge test}

Let's begin by reviewing the linear one-way model:

$$
y_{i t}=\alpha+\mathbf{X}_{i t} \boldsymbol{\beta}_{1}+\mathbf{Z}_{i} \boldsymbol{\beta}_{2}+\mu_{i}+\epsilon_{i t} \quad i \in\{1,2, \ldots, N\}, t \in\left\{1,2, \ldots, T_{i}\right\}
$$

Where "Yit" is the dependent variable; Xit is a $(1 \times \mathrm{K} 1)$ vector of time-varying covariates; $\mathrm{Zi}$ is a $(1 \times \mathrm{K} 2)$ vector of time-invariant covariates; $\alpha, \beta 1$, and $\beta 2$ are $1+\mathrm{K} 1+\mathrm{K} 2$ parameters; $\mu \mathrm{i}$ is the individual-level effect; and " $\mathrm{Q}$ " it is the idiosyncratic error. If the $\mu \mathrm{i}$ are correlated with the Xit or the $\mathrm{Zi}$, the coefficients on the time-varying covariates Xit can be consistently estimated by a regression on the within-transformed data or the first differenced data. If the $\mu \mathrm{i}$ are uncorrelated with the Xit and the $\mathrm{Zi}$, the coefficients on the time-varying and time-invariant covariates can be consistently and efficiently estimated using the feasible generalized least squares method known as random-effects regression.

\section{Pearson model}

The correlation coefficient $(\mathrm{r})$ is a statistical index that measures the correlation between two variables, such as between SATISFACTION LEVEL (y) and WAGE (x). The correlation coefficient has a value between -1 and 1 . A correlation coefficient of 0 (or near 0 ) means that the two variables are not related to each other; conversely if a coefficient of -1 or 1 means the two variables have an absolute relationship. If the value of the correlation coefficient is negative $(\mathrm{r}<0)$, it means that when $\mathrm{x}$ increases, $\mathrm{y}$ decreases (and vice versa, when $\mathrm{x}$ decreases, $\mathrm{y}$ increases); If the correlation coefficient value is positive $(r>0)$, it means that when $\mathrm{x}$ increases, $\mathrm{y}$ increases, and when $\mathrm{x}$ increases, $\mathrm{y}$ decreases. There are many correlation coefficients, the most common correlation coefficient: the Pearson $r$ correlation coefficient, defined as follows: Given two variables $\mathrm{x}$ and $\mathrm{y}$ from the sample $\mathrm{n}$, the Pearson correlation coefficient is estimated using the following formula:

$$
r=\frac{\sum_{i=1}^{n}\left(x_{i}-\bar{x}\right)\left(y_{i}-\bar{y}\right)}{\sqrt{\sum_{i=1}^{n}\left(x_{i}-\bar{x}\right)^{2} \sum_{i=1}^{n}\left(y_{i}-\bar{y}\right)^{2}}}
$$

In the analysis applied to the thesis, Pearson's correlation coefficient test is used to check the linear relationship between the independent and dependent variables. If the independent variables are strongly correlated, the multicollinearity problem must be considered when regression analysis (hypothesis H0: correlation coefficient equals 0 ).

\section{Multicollinearity (VIF coefficient)}

When using regression, we will use exact numbers to determine whether or not is collinear. Some statistical documents will state that if VIF is $<10$, there will be no collinearity. However, a rating of ten would be appropriate for topics on physics and techniques that do not use the Likert scale. Regarding economic and social topics, researchers think that VIF $>2$ will have the phenomenon of multicollinearity.

In short, this section irefers to theidesign of research the determinants influencing firms' performances of listed food processing firms using differentidataicollection, processing and analysisimethods based on theitable data derivedifrom the auditedifinancial statementsiof 35 food processingifirms for the period from 2012-2018.

Regression analysis is used for the design of quantitative research on the determinants influencing firms'iprofitability, in which, the dependent variables are Return on Assets (ROA), Return on Equity (ROE), Profit Margin (PM); independent variables including Debt Ratio (DR), Short-term to Total Assets (SDR), Long-term to Total Assets (LDR), Fixed Assets to Total Assets (FATA), TD/(TE+LTD), Size of firms (SIZE), Years of operation (AGE), Economic Growth rate (GDP), Inflation (I). Variables are explained in turn to give some hypotheses. All results are tested by the Hausman test, the modified Wald test statistic, the Pearson correlation coefficient, Wooldridge test as well as Multicollinearity (VIF coefficience) 


\section{Research results}

Table 3: Estimated Results of Regression Model ROE

\begin{tabular}{|c|c|c|}
\hline & Equation 1a & $\overline{\text { Equation } 1 \mathrm{~b}}$ \\
\hline$\overline{D R}$ & $\begin{array}{r}-0.8073732 \\
(-5.03)\end{array}$ & \\
\hline SDR & & $\begin{array}{r}-0.4473849 \\
(-6.61)\end{array}$ \\
\hline LDR & & $\begin{array}{r}-0.4327432 \\
(-4.21)\end{array}$ \\
\hline FATA & $\begin{array}{r}-0.3283924 \\
(-1.71)\end{array}$ & $\begin{array}{r}-0.1875834 \\
(-1.01)\end{array}$ \\
\hline TDTELT & $\begin{array}{r}0.2112263 \\
(6.98)\end{array}$ & $\begin{array}{r}0.2110868 \\
(9.86)\end{array}$ \\
\hline SIZE & $\begin{array}{r}0.090157 \\
(2.11)\end{array}$ & $\begin{array}{r}0.0209392 \\
(3.66)\end{array}$ \\
\hline _cons & $\begin{array}{r}0.1960764 \\
(1.17)\end{array}$ & $\begin{array}{r}0.1637774 \\
(0.98)\end{array}$ \\
\hline $\mathrm{N}$ & 245 & 245 \\
\hline
\end{tabular}

According to Table 3, the variables of Debt ratio (DR), Short-term debt ratio (SDR), Long-term debt ratio (LDR) have the negative impact with return on equity (ROE). On the other hand, TDTELT and SIZE has positive impact on return on equity (ROE). In addition, FATA impacts on ROE but has not statistically significant on it.

Based on the regression results presented in Table 3, we give regression equations of the following form:

(1) ROE $=0.1960764-0.8073732 *$ DR $-\mathbf{0 . 3 2 8 3 9 2 4} *$ FATA $+0.2112263 *$ TDTELT + 0.090157 * SIZE + e

(2) $\mathrm{ROE}=0.1637774-0.4473849 *$ SDR $-0.4327432 *$ LDR $-0.1875834 *$ FATA $+0.2110868 *$ TDTELT + $0.0209392 *$ SIZE + e

Equation 1 means:

$+\beta 1=-0.8073732$ indicates that when the DR increases by 1 time, in the condition that other factors remained constant, the average return on equity (ROE) decreases by 0.8073732 times.

$+\beta 2=-0.3283924$ reveals that when the FATA increases 1 time, in the condition that other factors remain unchanged, return on equity (ROE) will decrease by 0.3283924 times.

$+\beta 3=0.2112263$ shows that when TDTELT increased by 1 time, under other conditions, the average return on equity (ROE) increases by 0.2112263 times.

$+\beta 4=0.090157$ illustrates that when SIZE increased by 1 time, under other conditions, the average return on equity (ROE) increases by 0.090157 times.

Equation 2 means:

$+\beta 1=-0.4473849$ indicates that when the SDR increases by 1 time, in the condition that other factors remained constant, the average return on equity (ROE) decreases by 0.4473849 times.

$+\beta 2=-0.4327432$ indicates that when the LDR increases by 1 time, in the condition that other factors remained constant, the average return on equity (ROE) decreases by 0.4327432 times.

$+\beta 3=-0.1875834$ reveals that when the FATA increases 1 time, in the condition that other factors remain unchanged, return on equity (ROE) will decrease by 0.1875834 times.

$+\beta 4=0.2110868$ shows that when TDTELT increased by 1 time, under other conditions, the average return on equity (ROE) increases by 0.2110868 times.

$+\beta 5=0.0209392$ illustrates that when SIZE increased by 1 time, under other conditions, the average return on equity (ROE) increases by 0.0209392 times. 
Table 4: Estimated Results of Regression Model PM

\section{Equation 1a}

\begin{tabular}{lrr}
\hline DR & -0.6600119 & \\
SDR & $(-6.19)$ & -0.7696579 \\
& & $(-7.55)$ \\
LDR & & -0.3578893 \\
& & $(-3.01)$ \\
FATA & & -0.1354928 \\
& -0.0657974 & $(-1.11)$ \\
TDTELT & $(-0.52)$ & 0.160659 \\
& 0.1607277 & $(11.76)$ \\
SIZE & $(9.08)$ & -0.1447589 \\
& -0.1506611 & $(-3.12)$ \\
cons & $(-3.46)$ & 1.199096 \\
& 1.183108 & $(3.68)$ \\
$\mathrm{N}$ & $(3.39)$ & 245 \\
\hline $\mathrm{t}$ statistics in & 245 & $\mathrm{p}<0.01, * * * \mathrm{p}<0.001$ \\
\hline According to & parenthese $* \mathrm{p}<0.05, * *$ & .
\end{tabular}

According to Table 4, the variables of Debt ratio (DR), Short-term debt ratio (SDR), Long-term debt ratio (LDR) and SIZE have negative impacts with Profit margin (PM). On the other hand, TDTELT has positive impact on Profit margin (PM). In addition, FATA impacts on ROA but do not statistically significant on it.

Based on the regression results presented in Table 4, we give regression equations of the following form:

(1) $\mathrm{PM}=1.183108-0.6600119 * \mathrm{DR}-0.0657974 *$ FATA $+0.1607277 *$ TDTELT $-0.1506611 *$ SIZE + e

(2) $\mathrm{PM}=1.199096-\mathbf{0 . 7 6 9 6 5 7 9} * \mathrm{SDR}-\mathbf{0 . 3 5 7 8 8 9 3} *$ LDR $-\mathbf{0 . 1 3 5 4 9 2 8} *$ FATA + 0.160659 * TDTELT $0.1447589 *$ SIZE + e

Equation 1 means:

$+\beta 1=-0.6600119$ indicates that when the DR increases by 1 time, in the condition that other factors remained constant, the average Profit margin (PM) decreases by 0.266642 times.

$+\beta 2=-0.0657974$ reveals that when the FATA increases 1 time, in the condition that other factors remain unchanged, Profit margin (PM) will decrease by 0.1233716 times.

$+\beta 3=0.1607277$ shows that when TDTELT increased by 1 time, under other conditions, the average Profit margin (PM) increases by 0.0245583 times.

$+\beta 4=-0.1506611$ illustrates that when SIZE increased by 1 time, under other conditions, the average Profit margin (PM) decreases by 0.1506611 times.

Equation 2 means:

$+\beta 1=-0.7696579$ indicates that when the SDR increases by 1 time, in the condition that other factors remained constant, the average Profit margin (PM) decreases by 0.7696579 times.

$+\beta 2=-0.3578893$ indicates that when the LDR increases by 1 time, in the condition that other factors remained constant, the average Profit margin (PM) decreases by 0.3578893 times.

$+\beta 3=-0.1354928$ reveals that when the FATA increases 1 time, in the condition that other factors remain unchanged, Profit margin (PM) will decrease by 0.1354928 times.

$+\beta 4=0.160659$ shows that when TDTELT increased by 1 time, under other conditions, the average Profit margin $(\mathrm{PM})$ increases by 0.160659 times.

$+\beta 5=-0.1447589$ illustrates that when SIZE increased by 1 time, under other conditions, the average Profit margin (PM) decreases by 0.1447589 times.

\section{Conclusion}

This research has been run to study the factors influencing the Return on assets of food processing firms in the case of Vietnam. Author selected data from financial statements of 35 listed food processing firms for a 6-year period from 2012 to 2018 on Vietnam Stock Exchange. Through investigating the adjustment models of Return on Equity (ROE) and Profit Margin (PM), we notice that three factors of AGE, GDP growth and Inflation did not influence the profitability. On the contrary, TDTELT showed that it have had positive impact on ratios related to profitability. Meanwhile, SIZE positively impact with return on equity (ROE) while it impacts negatively on profit margin (PM). As the results of the study, some recommendations about capital structure should be effective for firms to make profit, so firms should take the following actions such as (i) recognize the importance of financial structure which may directly impacts business performance in making profit as well as business risk. In terms of capital structure, factors such as Debt Ratio (DR), Short-term debt ratio (SDR) negatively affect variables indicating the profitability. Accordingly, creating a logically financial structure is necessary in order to achieve greater profitability in the business. (ii) Besides financial structure, many other factors mentioned in the research 
affect profitability such as SIZE, GDP, and AGE. Thus, firms should be attentive to the influence of these determinants on profitability, thereby taking measures to improvise promptly. With the regards of Vietnam Food Association (VFA), the organization is of importance in qualifying and stimulating the food processing firms in Vietnam.

Particularly, VFA is established under Decision No.727/KDDN-QD on November 13, 1989 by the Ministry of Industry and Trade. Vietnam Food Association is a non-profit and non-governmental organization. The organization was established to help individuals, organizations and businesses operating in food production, food processing, food trading and agricultural products in Vietnam. Vietnam Food Association has a great responsibility to support food processing company which are giving proposals, advice and suggestions to state agencies on inappropriate regimes and policies which is detrimental to construction enterprises and adversely affecting the general development of society. VFA bridges the gap between firms by building cooperation, association and exchange of experience, Science \& Technology in operation for the purpose of improving business efficiency. Also, VFA becomes a focal H. Q. Bui et al. /Accounting 6 (2020) 9 point to recognize the difficulties of listed firms and advising the government on programs to support business development and increase production value. On the side of Stock Exchanges in Vietnam (Stock Exchange of Hanoi: HNX; and Stock Exchange of Ho Chi Minh City: HOSE), they play a great role in managing, encouraging listed food processing firms to improve. Therefore, the Stock Exchange should create conditions for businesses in the following aspects which are merging HOSE and HNX in order to facilitate listed firms to have the same operating environment. Also, it strengthens the monitoring function for listed firms, create strong sanctions against companies that intentionally cheat information. Based on the data of listed food firms, the Stock Exchange should calculate more than the average economic indicators of the industry, from which businesses can compare and position themselves.

\section{References}

Harris, M., \& Raviv, A. (1991). The theory of Capital Structure. Journal of Finance, 46, 297-355.

Myers, S.C. (1984). The Capital Structure Puzzle. Journal of Finance, 39, 575-592.

Nguyen, H.C. (2016). Capital Structure and Firm's Performance: Evidence from HOSE. Master Thesis. Berlin School of Economics and Law.

Pham, T.M and Nguyen, T.D (2015), Factors affecting capital structure from static model to dynamic model: Research in Real estate industry in Vietnam.

Serrasqueiro, Z. and Nunes, P. (2008). Performance and size: empirical evidence from Portuguese SMEs. Small Business Economics, 31(2), 195-217.

Shepherd, W.G. (1972). The Elements of Market Structure. Review of Economics and Statistics, 54, 25-35.

Tandelilin, E. (2010). Portofolio dan Investasi Teori dan Aplikasi (Edisi Pert). Yogyakarta: Kanisius. Indonesia.

Trinh, T.P.L (2013), Real estate companies: Risks from Financial Structure, Journal of Economics and Business, $3,24-31$.

Vo, T.T.A \& Bui, P.N.K (2012), The factors influencing enterprises' financial structure: An application in the manufacturing companies listed on HOSE, Journal of Economics Development, 260, 33-40. 